\section{INVESTIGASI KECELAKAAN PESAWAT UDARA SIPIL MENURUT UNDANG-UNDANG NOMOR 1 TAHUN 2009 TENTANG PENERBANGAN ${ }^{1}$ Oleh: Joshua Tambalean ${ }^{2}$}

\begin{abstract}
ABSTRAK
Tujuan dilakukannya penelitian ini adalah untuk mengetahui bagaimana investigasi kecelakaan pesawat udara sipil menurut Undang-Undang Nomor 1 Tahun 2009 Tentang Penerbangan dan bagaimana penyelidikan lanjutan kecelakaan pesawat udara sipil menurut Undang-Undang Nomor 1 Tahun 2009 Tentang Penerbangan. Dengan menggunakan metode penelitian yuridis normatif, disimpulkan: 1 . Investigasi kecelakaan pesawat udara sipil dilakukan oleh pemerintah untuk mengetahui penyebab setiap kecelakaan dan kejadian serius terhadap pesawat udara sipil yang terjadi di wilayah Republik Indonesia. Pelaksanaan investigasi dan penyelidikan lanjutan dilakukan oleh komite nasional yang dibentuk dan bertanggung jawab kepada Presiden. Komite nasional adalah institusi yang independen dalam menjalankan tugas dan fungsinya serta memiliki keanggotaan yang dipilih berdasarkan standar kompetensi melalui uji kepatutan dan kelayakan oleh Menteri. 2. Penyelidikan lanjutan kecelakaan pesawat udara sipil dilakukan oleh majelis profesi penerbangan yang dibentuk Komite Nasional untuk melaksanakan penyelidikan lanjutan, penegakan etika profesi, pelaksanaan mediasi dan penafsiran penerapan regulasi. Majelis profesi penerbangan berasal dari unsur profesi, pemerintah, dan masyarakat yang kompeten di bidang hukum; pesawat udara; navigasi penerbangan; bandar udara; kedokteran penerbangan; dan Penyidik Pegawai Negeri Sipil.

Kata kunci: Investigasi, Kecelakaan, Pesawat Udara Sipil, Penerbangan
\end{abstract}

\section{PENDAHULUAN}

\section{A. Latar Belakang}

Investigasi kecelakaan dan penyelidikan lanjutan atas kecelakaan pesawat udara sipil dimaksudkan untuk melakukan kegiatan

\footnotetext{
${ }^{1}$ Artikel Skripsi. Dosen Pembimbing: Hengky A. Korompis, $\mathrm{SH}, \mathrm{MH}$; Fernando J. M. M. Karisoh, SH, MH

2 Mahasiswa pada Fakultas Hukum Unsrat, NIM. 16071101471
}

penelitian terhadap penyebab kecelakaan pesawat udara sipil dengan cara mengumpulkan data untuk diolah dan dianalisis guna mencegah terjadinya kecelakaan transportasi dengan penyebab yang sama. Undang-Undang Nomor 1 Tahun 2009 Tentang Penerbangan mengatur mengenai investigasi untuk memberikan kepastian hukum mengenai jaminan perlindungan keamanan dan keselamatan penerbangan apabila terjadi kecelakaan.

Kepastian hukum keadilan dan kemanfaatan merupakan tujuan hukum yang perlu dimasukan dalam pembentukan peraturan perundang-undangan, agar supaya ketentuanketentuan hukum dapat mencerminkan keadilan bagi masyarakat dan mewujudkan nilai-nilai kemanusiaan khususnya bagi pemakai jasa transportasi udara agar dapat terhindar dari kecelakaan transportasi udara.

Norma hukum tidak bertentangan dengan rasa keadilan masyarakat dan martabat manusia. Norma hukum justru memungkinkan manusia mewujudkan nilai-nilai kemanusiaan, seperti kerukunan atau kebersamaan, solidaritas, kebebasan, perdamaian dan kasih sayang. Dengan demikian hukum yang baik harus tepat (secara formal) dan pasti serta adil (secara materiil) sehingga bisa mewujudkan rasa keadilan, harmoni dan kebaikan umum yang menjadi tujuan hukum itu sendiri. Hukum yang baik adalah hukum yang benar dan adil sehingga memiliki keabsahan dalam mengikat, mewajibkan dan dapat dipaksakan untuk dijalankan. $^{3}$

Hukum yang baik mengondisikan pembuatan dan pelaksanaan aturan hukum sesuai dengan martabat manusia. Dengan mematuhi hukum yang baik, kebebasan seseorang tidak hilang dan karenanya martabatnya sebagai manusia pun tidak direndahkan, bahkan dengan menaati hukum yang baik, ia justru mewujudkan keluhuran martabatnya karena ia menyadari dan memahami apa yang ditaatinya. Dalam kepatuhan itu, ia bebas untuk memilih untuk menaati hukum demi pengaktualisasian martabatnya sebagai manusia dalam interaksi sosial dengan orang lain. ${ }^{4}$

\footnotetext{
${ }^{3}$ Muhammad Nuh. Etika Profesi Hukum. CV. Pustaka Setia. Bandung. 2011. hlm. 199.

${ }^{4}$ Ibid.
} 


\section{B. Rumusan Masalah}

1. Bagaimanakah investigasi kecelakaan pesawat udara sipil menurut UndangUndang Nomor 1 Tahun 2009 Tentang Penerbangan?

2. Bagaimanakah penyelidikan lanjutan kecelakaan pesawat udara sipil menurut Undang-Undang Nomor 1 Tahun 2009 Tentang Penerbangan?

\section{Metode Penelitian}

Metode penelitian yang digunakan untuk menyusun penulisan ini ialah metode penelitian hukum normatif dengan menggunakan datadata sekunder yang diperoleh dari studi kepustakaan. Data sekunder terdiri atas bahanbahan hukum primer, sekunder dan tersier. Bahan hukum primer berupa peraturan perundang-undangan yang mengatur mengenai penerbangan. Bahan hukum sekunder berupa literatur-literatur dan karya-karya ilmiah hukum dan bahan hukum tersier dan juga seperti kamus-kamus umum dan kamus-kamus hukum.

Penelitian hukum yang dilakukan dengan cara meneliti bahan pustaka atau data sekunder belaka, dapat dinamakan penelitian hukum normatif atau penelitian hukum kepustakaan (di samping adanya penelitian hukum sosiologis atau empiris yang terutama meneliti data primer). ${ }^{5}$

\section{PEMBAHASAN}

A. Investigasi Kecelakaan Pesawat Udara Sipil Menurut Undang-Undang Nomor 1 Tahun 2009 Tentang Penerbangan

Undang-Undang Nomor 1 Tahun 2009

Tentang Penerbangan. Pasal 357 ayat:

(1) Pemerintah melakukan investigasi dan penyelidikan lanjutan mengenai penyebab setiap kecelakaan dan kejadian serius pesawat udara sipil yang terjadi di wilayah Republik Indonesia.

(2) Pelaksanaan investigasi dan penyelidikan lanjutan sebagaimana dimaksud pada ayat (1) dilakukan oleh komite nasional yang dibentuk dan bertanggung jawab kepada Presiden.

\footnotetext{
${ }^{5}$ Soerjono Soekanto dan Sri Mamudji, Penelitian Hukum Normatif Suatu Tinjauan Singkat, PT Raja Grafindo Persada, Jakarta. 1995, hlm. 13-14.
}

(3) Komite nasional sebagaimana dimaksud pada ayat (2) adalah institusi yang independen dalam menjalankan tugas dan fungsinya serta memiliki keanggotaan yang dipilih berdasarkan standar kompetensi melalui uji kepatutan dan kelayakan oleh Menteri.

(4) Komite nasional sebagaimana dimaksud pada ayat (2) bertugas melakukan kegiatan investigasi, penelitian, penyelidikan lanjutan, laporan akhir, dan memberikan rekomendasi dalam rangka mencegah terjadinya kecelakaan dengan penyebab yang sama.

(5) Rekomendasi sebagaimana dimaksud pada ayat (4) wajib dan segera ditindaklanjuti oleh para pihak terkait.

Peraturan Presiden Republik Indonesia Nomor 2 Tahun 2012 Tentang Komite Nasional Keselamatan Transportasi. Pasal 1. Dalam Peraturan Presiden ini yang dimaksud dengan:

1. Transportasi adalah salah satu mata rantai jaringan distribusi barang dan mobilitas penumpang yang berkembang sangat dinamis, serta berperan di dalam mendukung, mendorong, dan menunjang segala aspek kehidupan, baik dalam pembangunan politik, ekonomi, sosial budaya, dan pertahanan keamanan.

2. Kecelakaan transportasi adalah peristiwa atau kejadian pengoperasian sarana transportasi yang mengakibatkan kerusakan sarana transportasi dimaksud, korban jiwa dan/atau kerugian harta benda.

3. Investigasi kecelakaan transportasi adalah kegiatan penyelidikan dan penelitian terhadap penyebab kecelakaan transportasi dengan cara pengumpulan, pengolahan, analisis, dan penyajian data secara sistematis, dan obyektif agar kecelakaan transportasi dengan penyebab yang sama tidak terulang kembali.

4. Investigator adalah orang yang mempunyai kualifikasi dan kompetensi tertentu untuk melaksanakan kegiatan investigasi kecelakaan transportasi.

Pasal 2. Sampai dengan terbentuknya kelembagaan yang bertugas melaksanakan investigasi kecelakaan transportasi sebagaimana dimaksud dalam Undang-Undang 23 Tahun 2007 tentang Perkeretaapian, Undang-Undang Nomor 17 Tahun 2008 tentang 
Pelayaran, dan Undang-Undang Nomor 1 Tahun 2009 tentang Penerbangan, Komite Nasional Keselamatan Transportasi yang selanjutnya disebut dengan KNKT, yang dibentuk dengan Keputusan Presiden Nomor 105 Tahun 1999 tentang Komite Nasional Keselamatan Transportasi diteruskan keberadaannya berdasarkan Peraturan Presiden ini.

Pasal 3.

(1) KNKT merupakan lembaga non-struktural yang berada di bawah dan bertanggung jawab kepada Presiden.

(2) KNKT dipimpin oleh seorang Ketua.

Tugas. Pasal 4. KNKT mempunyai tugas:

(1) melaksanakan investigasi kecelakaan transportasi;

(2) memberikan rekomendasi hasil investigasi kecelakaan transportasi kepada pihak terkait; dan

(3) memberikan saran dan pertimbangan kepada Presiden berdasarkan hasil investigasi kecelakaan transportasi dalam rangka mewujudkan keselamatan transportasi.

Pasal 5. Pelaksanaan tugas investigasi kecelakaan transportasi oleh KNKT sebagaimana dimaksud dalam Pasal 4 huruf a dilakukan tidak untuk menentukan kesalahan dan kelalaian atas terjadinya kecelakaan transportasi.

Pasal 6.

(1) Dalam melaksanakan tugas sebagaimana dimaksud dalam Pasal 4 huruf a, KNKT dapat:

a. bekerja sama dengan pihak lain; dan

b. meminta data dan keterangan kepada pejabat instansi terkait, lembaga/organisasi profesi terkait, masyarakat, dan/atau pihak lain yang dipandang perlu.

(2) Pejabat instansi terkait sesuai dengan tugas dan fungsinya, memberikan data dan keterangan yang diminta KNKT sebagaimana dimaksud pada ayat (1) huruf b, yang pelaksanaannya dilakukan sesuai dengan ketentuan peraturan perundangundangan.

Pasal 7.

(1) Pelaksanaan tugas pemberian rekomendasi hasil investigasi kecelakaan transportasi kepada pihak terkait oleh KNKT sebagaimana dimaksud dalam Pasal 4 huruf b dimaksudkan untuk mencegah terjadinya kecelakaan transportasi dengan penyebab yang sama.

(2) Rekomendasi hasil investigasi kecelakaan transportasi sebagaimana dimaksud pada ayat (1) ditindaklanjuti oleh para pihak terkait sesuai dengan ketentuan peraturan perundang-undangan.

(3) KNKT dapat melakukan klarifikasi dan monitoring terhadap proses tindak lanjut atas rekomendasi hasil investigasi kecelakaan transportasi sebagaimana dimaksud pada ayat (1) dan ayat (2) yang dilakukan oleh pihak terkait.

Pasal 8 ayat:

(1) Pelaksanaan tugas pemberian saran dan pertimbangan kepada Presiden oleh KNKT sebagaimana dimaksud dalam Pasal 4 huruf c dilakukan untuk perumusan kebijakan transportasi dan upaya pencegahan kecelakaan transportasi.

(2) Saran dan pertimbangan kepada Presiden sebagaimana dimaksud pada ayat (1) disampaikan melalui Menteri Perhubungan.

Pasal 9. Dalam melaksanakan tugasnya, KNKT dikoordinasikan oleh Menteri Perhubungan. Pasal 10. Dalam melaksanakan tugasnya, KNKT:

a. bersifat mandiri; dan

b. bertanggung jawab atas obyektivitas dan kebenaran hasil investigasi kecelakaan transportasi.

Pasal 11. Dalam melaksanakan tugasnya, KNKT wajib:

a. menaati norma hukum dan ketentuan peraturan perundang-undangan; dan

b. menjaga kerahasiaan keterangan yang karena sifatnya merupakan rahasia KNKT yang diperoleh berdasarkan kedudukannya sebagai anggota. ${ }^{6}$

KNKT dalam Data Investigasi Kecelakaan Penerbangan Tahun 2010-2016 (PDF) menyebut bahwa mayoritas utama penyebab kecelakaan penerbangan terjadi karena faktor manusia (67,12\%). Selain faktor manusia, ada beberapa faktor penyebab lain yang menjadi faktor pesawat celaka. Namun, persentasenya lebih kecil. Faktor teknis, misalnya, menyumbang 15,75 persen kecelakaan. Begitu juga faktor lingkungan yang membuat 12,33

${ }^{6}$ Peraturan Presiden Republik Indonesia Nomor 2 Tahun 2012 Tentang Komite Nasional Keselamatan Transportasi. 
persen kasus dari periode sepuluh tahun itu. Faktor human error seperti menegaskan bahwa peralatan canggih dan mutakhir pun tidak menjamin nir-kecelakaan dalam penerbangan. Kasus pesawat Adam Air jatuh di perairan Sulawesi Selatan pada 2007 dapat menjadi bukti. Hasil investigasi KNKT memberi kesimpulan akhir bahwa penyebab kecelakaan adalah kesalahan pilot. ${ }^{7}$

Peraturan Pemerintah Republik Indonesia Nomor 62 Tahun 2013 Tentang Investigasi Kecelakaan Transportasi. Pasal 1 angka 1. Investigasi Kecelakaan Transportasi adalah kegiatan penelitian terhadap penyebab kecelakaan transportasi dengan cara pengumpulan, pengolahan, analisis, dan penyajian data secara sistematis dan objektif agar tidak terjadi kecelakaan transportasi dengan penyebab yang sama. Pasal 1 angka 2 . Kecelakaan Transportasi adalah peristiwa atau kejadian pengoperasian sarana transportasi yang mengakibatkan kerusakan sarana transportasi, korban jiwa, dan/atau kerugian harta benda.

Pasal 2. Investigasi Kecelakaan Transportasi diselenggarakan berdasarkan prinsip:

a. tidak untuk mencari kesalahan (no blame);

b. tidak untuk memberikan sanksi/hukuman (no judicial); dan

c. tidak untuk mencari siapa yang bertanggung jawab menanggung kerugian (no liability).

Pasal 3. Investigasi Kecelakaan Transportasi diselenggarakan untuk mengungkap suatu peristiwa kecelakaan transportasi secara profesional dan independen guna memperoleh data dan fakta penyebab terjadinya kecelakaan transportasi. Pasal 4. Pelaksanaan Investigasi Kecelakaan Transportasi sebagaimana dimaksud dalam Pasal 3 dilakukan oleh Komite Nasional Keselamatan Transportasi. Pasal 5. Kedudukan, Tugas, dan Organisasi Komite Nasional Keselamatan Transportasi diatur dengan Peraturan Presiden. Pasal 6. Investigasi Kecelakaan Transportasi dilakukan terhadap:
a. kecelakaan Kereta Api;
b. kecelakaan Kapal;
c. kecelakaan Pesawat Udara; dan
d. kecelakaan tertentu kendaraan bermotor umum.

Pasal 9. Kecelakaan Pesawat Udara sebagaimana dimaksud dalam Pasal 6 huruf $\mathrm{c}$ terdiri atas:

a. Pesawat Udara yang jatuh pada saat tinggal landas, lepas landas, atau selama penerbangan;

b. Tabrakan antar Pesawat Udara atau antar Pesawat Udara dengan fasilitas di bandar udara;

c. Pesawat Udara yang hilang atau tidak dapat diketemukan; dan/atau

d. Pesawat Udara yang mengalami Kejadian Serius (serious incident).

Pasal 22. Setiap kecelakaan Pesawat Udara dan Kejadian Serius Pesawat Udara sebagaimana dimaksud dalam Pasal 16 wajib diberitahukan kepada Komite Nasional Keselamatan Transportasi oleh:

a. badan usaha angkutan udara;

b. penyedia jasa penerbangan; atau

c. kementerian yang menyelenggarakan pemerintahan dibidang transportasi.

Pasal 2 Komite Nasional Keselamatan Transportasi wajib segera meneruskan pemberitahuan kecelakaan Pesawat Udara atau Kejadian Serius sebagaimana dimaksud dalam Pasal 22 kepada:

a. negara tempat pesawat terdaftar;

b. negara operator;

c. negara tempat perancang pesawat;

d. negara industri pesawat atau komponen; dan

e. international Civil Aviation Organization apabila berat pesawat melebihi $2.250 \mathrm{Kg}$ (dua ribu dua ratus lima puluh kilogram).

Pelaksanaan Investigasi Kecelakaan Transportasi. Pasal 26.

(1) Setelah menerima pemberitahuan terjadinya kecelakaan Kereta Api, Kapal, dan Pesawat Udara, sebagaimana dimaksud dalam Pasal 20, Pasal 21, dan Pasal 22, Komite Nasional Keselamatan Transportasi melakukan persiapan investigasi.

(2) Persiapan investigasi sebagaimana dimaksud pada ayat (1) meliputi:
a. membentuk tim investigasi;
b. mempersiapkan peralatan investigasi; dan
c. melakukan koordinasi dengan instansi terkait atau operator sarana transportasi yang mengalami kecelakaan.


(3) Tim investigasi sebagaimana dimaksud pada ayat (2) huruf a ditetapkan oleh Ketua Komite Nasional Keselamatan Transportasi.

Pasal 27. Setelah persiapan investigasi sebagaimana dimaksud dalam Pasal 26, Komite Nasional Keselamatan Transportasi melakukan investigasi awal di lokasi Kecelakaan Transportasi.

Pasal 28. Investigasi awal sebagaimana dimaksud dalam Pasal 27 paling sedikit dilakukan dengan:

a. mengumpulkan data dan barang bukti Kecelakaan Transportasi;

b. mengambil gambar atau foto;

c. mendata korban; dan/atau

d. mengumpulkan informasi dan keterangan di lokasi Kecelakaan Transportasi dari pihak yang mengetahui kejadian kecelakaan. ${ }^{8}$

\section{B. Penyelidikan Lanjutan Kecelakaan Pesawat Udara Sipil Menurut Undang-Undang Nomor 1 Tahun 2009 Tentang Penerbangan}

Undang-Undang Nomor 1 Tahun 2009 Tentang Penerbangan, mengatur mengenai Penyelidikan Lanjutan Kecelakaan Pesawat Udara. Pasal 364. Untuk melaksanakan penyelidikan lanjutan, penegakan etika profesi, pelaksanaan mediasi dan penafsiran penerapan regulasi, komite nasional membentuk majelis profesi penerbangan.

Penjelasan Pasal 364 Yang dimaksud dengan "penyelidikan lanjutan" adalah suatu proses untuk memberikan perlindungan dan kepastian hukum bagi personel penerbangan atas tindakan, keputusan atau pengabaian yang dilakukan berdasarkan hasil pelatihan dan pengalamannya (actions, omissions or decisions taken by them that are commensurate with their experience and training) serta penentuan dari sisi profesi perilaku mana yang dapat diterima atau yang tidak dapat ditoleransi (the role of domain expertise be in judging whether is acceptable or unacceptable).

Pasal 365. Majelis profesi penerbangan sebagaimana dimaksud dalam Pasal 364 mempunyai tugas:

a. menegakkan etika profesi dan kompetensi personel di bidang penerbangan;

8 Peraturan Pemerintah Republik Indonesia Nomor 62 Tahun 2013 Tentang Investigasi Kecelakaan Transportasi. b. melaksanakan mediasi antara penyedia jasa penerbangan, personel dan pengguna jasa penerbangan; dan

c. menafsirkan penerapan regulasi di bidang penerbangan.

Pasal 366. Dalam pelaksanaan tugas sebagaimana dimaksud dalam Pasal 365 majelis profesi penerbangan memiliki fungsi:

a. menegakkan etika profesi dan kompetensi personel penerbangan;

b. menjadi mediator penyelesaian sengketa perselisihan di bidang penerbangan di luar pengadilan; dan

c. menjadi penafsir penerapan regulasi di bidang penerbangan.

Pasal 367. Majelis profesi penerbangan sebagaimana dimaksud dalam Pasal 364 paling sedikit berasal dari unsur profesi, pemerintah, dan masyarakat yang kompeten di bidang:

a. hukum;

b. pesawat udara;

c. navigasi penerbangan;

d. bandar udara;

e. kedokteran penerbangan; dan

f. Penyidik Pegawai Negeri Sipil.

Pasal 368. Majelis profesi penerbangan berwenang:

a. memberi rekomendasi kepada Menteri untuk pengenaan sanksi administratif atau penyidikan lanjut oleh PPNS;

b. menetapkan keputusan dalam sengketa para pihak dampak dari kecelakaan atau kejadian serius terhadap pesawat udara; dan

c. memberikan rekomendasi terhadap penerapan regulasi penerbangan. Pasal 369 Ketentuan lebih lanjut mengenai investigasi kecelakaan pesawat udara dan penyelidikan lanjutan diatur dengan Peraturan Pemerintah.

Perkembangan teknologi penerbangan mempunyai dampak yang positif terhadap keselamatan penerbangan dalam dan luar negeri. ${ }^{9}$ Responsibility dan liability. Istilah responsibility lebih menunjuk kepada indikator penentu lahirnya tanggung jawab, yaitu standar perilaku yang telah ditetapkan terlebih dahulu dalam bentuk kewajiban yang harus ditaati, serta saat lahirnya suatu tanggung jawab, sedangkan istilah liability lebih menunjuk kepada akibat yang timbul dari akibat

\footnotetext{
${ }^{9}$ K. Martono, Tim Analisis Awak Pesawat Udara Sipil, Jakarta, 1999, hlm 1.
} 
kegagalan untuk memenuhi standar itu; dan bentuk tanggung jawab yang harus diwujudkan dalam kaitan dengan akibat atau kerugian yang timbul akibat kegagalan memenuhi kewajiban tersebut, yaitu pemulihan (legal redress). ${ }^{10}$

Pada mulanya istilah itu hanya digunakan untuk menunjuk standar, perilaku dan saat lahirnya tanggung jawab, serta tidak terlalu dihubungkan dengan masalah kerugian, besar kerugian, maupun pembayarannya, tetapi dalam perkembangannya istilah itu mendapat pengertian yang agak berbeda, yaitu lebih menunjuk kepada pengertian liability, yaitu tanggung jawab berdasarkan prinsip ganti rugi, besar kerugian dan cara pemulihannya. ${ }^{11}$

Pengertian ini menunjukan bahwa tanggung jawab dapat direalisasikan dalam dua bentuk, menurut sifat kerugian yang harus diatasinya, yaitu: pertama, yang berbentuk tindakan pemulihan kerugian atau pembayaran ganti rugi (represif); dan kedua, yang berbentuk pencegahan timbulnya kerugian (preventif). Wujud yang pertama berkaitan dengan kerugian yang dapat diperhitungkan dan dipulihkan, sedangkan wujud yang kedua berkaitan dengan kerugian yang tidak dapat diperhitungkan dan dipulihkan melalui proses pembayaran ganti rugi. ${ }^{12}$

Dalam suatu penerbangan setidaknya ada tiga pihak yang dapat dimintakan pertanggungjawaban apabila terjadi kecelakaan. Pihak-pihak tersebut adalah pengelola bandar udara, maskapai penerbangan, dan awak pesawat. Untuk pengangkutan udara internasional ketentuanketentuan yang mengatur tanggung jawab pengangkut udara terhadap penumpang terdapat dalam Pasal 17 Konvensi Warsawa yang berbunyi: "The carrier shall be liable for damage sustained in the event of death, wounding or any other bodily injury by a passenger if the accident which caused the damaged so suistained took place on board the aircraft or in the course of any of the operations of embarking ordisembarking". ${ }^{13}$

\footnotetext{
${ }^{10}$ Ida Bagus Wyasa Putra, Tanggung Jawab Negara Terhadap Dampak Komersialisasi Ruang Angkasa, Refika Aditama, Bandung, 2001, hlm. 54.

${ }^{11}$ Ibid.

12 Ibid.

${ }^{13}$ E. Saefullah Wiradipradja, Hukum Transportasi Udara: Dari Warsawa 1929 ke Montreal 1999, P.T. Kiblat Buku Utama, 2008, hlm. 112.
}

Berdasarkan Pasal 17 tersebut, untuk menyatakan bahwa pengangkut bertanggung jawab atas kerugian yang timbul harus dipenuhi syarat-syarat seperti berikut:

a. kerugian harus disebabkan oleh suatu kecelakaan (accident)

b. kecelakaan (accident) tersebut harus terjadi dalam pesawat (on board the aircraft); atau

c. kecelakan tersebut harus terjadi pada waktu embarkasi atau disembarkasi (or in the course of any of the operations of embarking or disembarking). ${ }^{14}$

Untuk pengangkutan udara domestik ruang lingkup tanggung jawab pengangkut udara domestik Indonesia diatur dalam Pasal 24 Ordonansi 1939 yang menyatakan: "Pengangkut bertanggung jawab untuk kerugian sebagai akibat dari luka atau cacatcacat lain pada tubuh, yang diderita oleh seorang penumpang, bila kecelakaan yang menimbulkan kerugian itu ada hubungannya dengan pengangkutan udara dan terjadi diatas pesawat terbang atau selama melakukan suatu tindakan dalam hubungan dengan naik atau turun dari pesawat terbang. ${ }^{15}$ Dengan adanya ketentuan demikian, ruang lingkup tanggung jawab pengangkut udara domestik Indonesia lebih sempit dibanding dengan ruang lingkup tanggung jawab pengangkut pada pengangkutan udara internasional dan posisi pengangkut udara domestik lebih baik dibanding dengan posisi pengangkut dalam pengangkutan udara internasional. ${ }^{16}$

Indonesia dan Arab Saudi menandatangi Memorandum of Cooperation (MoC) mengenai investigasi kecelakaan penerbangan. Dalam siaran pers yang diterima Radio Republik Indonesia, Senin (3/12/2018), penandatangan MoC oleh Ketua Komite Nasional Keselamatan Transportasi (KNKT) Indonesia, Soerjanto Tjahjono, dan Direktur Jenderal Biro Investigasi Penerbangan atau Aviation Investigation Bureau (AIB) Arab Saudi, Mr. Abdulelah O Felemban, berlangsung Kamis, 29 November 2018. Prosesi pendantangan berlangsung di kantor AIB dengan dihadiri oleh jajaran pejabat AIB dan delegasi pejabat dari KNKT didampingi oleh Amiruddin Muhammad Arsyad, Atase/Staf Teknis Perhubungan, dan Tubagus Muhammad

\footnotetext{
${ }^{14} \mathrm{Ibid}$.

${ }^{15}$ Luchtvervoer Ordonantie-Staatsblad 1939 No. 100

${ }^{16}$ E. Saefullah Wiradipradja, Op.Cit. hlm. 246.
} 
Nafia, Pelaksana Fungsi Pensosbud-2 Konsul Jenderal Republik Indonesia (KJRI) Jeddah. ${ }^{17}$

Kerja sama bilateral antara RI dan Kerajaan Arab Saudi di bidang investigasi kecelakaan pesawat terbang ini digagas pada acara regional workshop di Jeddah yang digelar Maret 2018, yang dihadiri oleh perwakilan sejumlah negara termasuk KNKT Indonesia dan Atase/Staf Teknis Perhubungan KJRI Jeddah. Delegasi RI dan Arab Suadi mengadakan pertemuan bilateral yang menghasilkan draft Memorandum of Cooperation, yang fokus utamanya adalah untuk peningkatan keselamatan penerbangan. Indonesia dan Arab Saudi merupakan sesama negara anggota International Civil Aviation Organization (ICAO) atau Organisasi Penerbangan Sipil Internasional. Kedua negara telah sepakat untuk meningkatkan keselamatan penerbangan sebagaimana dimandatkan oleh Annex 13 Konvensi Chicago, dengan fokus kegiatan konkrit yaitu pelatihan, pertukaran keahlian, informasi dan pengalaman. ${ }^{18}$

Ruang lingkup kerja sama ini, antara lain, pertama, mencakup penawaran bantuan dan penggunaan tenaga investigasi keselamatan angkutan udara, fasilitas dan peralatan yang dinilai tepat dan sebagai sumber daya yang memadai. Bantuan tersebut dapat mencakup keahlian di bidang teknik, operasional, perekam penerbangan, sumber daya manusia dan manajemen organisasi. Kedua, adalah memfasilitasi keikutsertaan investigator pihak lain sebagai pengamat pada investigasi kecelakaan pesawat udara dan insiden serius. Tujuannya adalah untuk meningkatkan pemahaman pihak lain terkait persyaratan dan prosedur investigasi. Ketiga, sumber daya, jika mengizinkan, dapat menurunkan bantuan tim pada proses investigasi (termasuk spesialis perekam penerbangan dan spesialis teknis lainnya) kepada pihak yang meminta untuk menjadi anggota tim investigasi pada saat melaksanakan investigasi. Keempat, mengadakan kontak secara teratur dan mengatur kunjungan atau pertemuan dengan

\footnotetext{
17 http://rri.co.id/berita/nasional.html. KNKT dan AIB Tandatangani MoC Bidang Investigasi Kecelakaan Penerbangan. Diakses 8/20/2019 8:28 Wita.

${ }^{18}$ Ibid.
}

pihak lain dengan tujuan bertukar pengalaman, keterampilan, dan pengetahuan teknis. ${ }^{19}$

Pengaturan yang dibentuk oleh penguasa negara menimbulkan norma hukum. Kaidah tersebut berupa peraturan-peraturan dalam segala bentuk dan jenisnya. $\mathrm{Di}$ dalam kehidupan sehari-hari terbukti bahwa norma hukum mengikat setiap orang. Pelaksanaan norma hukum mengikat setiap orang. Pelaksanaan norma hukum dapat dipaksakan dan dipertahankan oleh negara. Dipertahankan dan dipaksakannya norma hukum oleh negara merupakan salah satu keistimewaan norma hukum dengan ancaman pidana (bagi hukum pidana), hukuman (bagi hukum perdata dan atau hukum dagang). Upaya mewujudkan pertahanan dan paksaan tersebut tidak mungkin dapat berjalan dengan sendirinya akan tetapi hal itu harus dilaksanakan oleh alat-alat kekuasaan negara. Pelaksanaan tersebut bukan berarti tindakan sewenang-wenang akan tetapi merupakan upaya agar peraturan tersebut ditaati dan terlaksana dengan sebaik-baiknya. ${ }^{20}$

Investigasi terhadap kecelakaan pesawat udara sipil dan adanya upaya penyelidikan lanjutan atas kecelakaan pesawat udara sipil menurut Undang-Undang Nomor 1 Tahun 2009 Tentang Penerbangan merupakan bagian dari upaya pencegahan agar tidak lagi terjadi kecelakaan pesawat udara sipil yang disebabkan oleh faktor-faktor penyebab yang sama. Hal ini diperlukan mengingat aktivitas penerbangan perlu dikembangkan agar mampu meningkatkan pelayanan yang lebih luas, baik domestik maupun internasional.

\section{PENUTUP}

\section{A. Kesimpulan}

1. Investigasi kecelakaan pesawat udara sipil dilakukan oleh pemerintah untuk mengetahui penyebab setiap kecelakaan dan kejadian serius terhadap pesawat udara sipil yang terjadi di wilayah Republik Indonesia. Pelaksanaan investigasi dan penyelidikan lanjutan dilakukan oleh komite nasional yang dibentuk dan bertanggung jawab kepada Presiden. Komite nasional adalah institusi yang independen dalam menjalankan

\footnotetext{
${ }^{19}$ Ibid.

${ }^{20}$ Sudarsono, Pengantar Ilmu Hukum, Cetakan Kelima, PT. Rineka Cipta, Jakarta, 2007. hlm. 166.
} 
tugas dan fungsinya serta memiliki keanggotaan yang dipilih berdasarkan standar kompetensi melalui uji kepatutan dan kelayakan oleh Menteri.

2. Penyelidikan lanjutan kecelakaan pesawat udara sipil dilakukan oleh majelis profesi penerbangan yang dibentuk Komite Nasional untuk melaksanakan penyelidikan lanjutan, penegakan etika profesi, pelaksanaan mediasi dan penafsiran penerapan regulasi. Majelis profesi penerbangan berasal dari unsur profesi, pemerintah, dan masyarakat yang kompeten di bidang hukum; pesawat udara; navigasi penerbangan; bandar udara; kedokteran penerbangan; dan Penyidik Pegawai Negeri Sipil.

\section{B. Saran}

1. Dalam melakukan investigasi terhadap kecelakaan pesawat udara sipil, Komite nasional wajib melakukan kegiatan investigasi, penelitian, penyelidikan lanjutan, laporan akhir, dan memberikan rekomendasi dalam rangka mencegah terjadinya kecelakaan dengan penyebab yang sama. Rekomendasi Komite nasional wajib dan segera ditindaklanjuti oleh para pihak terkait.

2. Dalam pelaksanaan penyelidikan lanjutan kecelakaan pesawat udara sipil oleh Majelis profesi penerbangan wajib melaksanakan kewenangannya untuk memberi rekomendasi kepada Menteri mengenai pengenaan sanksi administratif atau penyidikan lanjut oleh PPNS (Pejabat Pegawai Negeri Sipil) dan menetapkan keputusan dalam sengketa para pihak dampak dari kecelakaan atau kejadian serius terhadap pesawat udara; serta memberikan rekomendasi terhadap penerapan regulasi penerbangan.

\section{DAFTAR PUSTAKA}

\section{A. Literatur}

H. Suratman, dan Philips Dillah, Metode Penelitian Hukum, Alfabeta, Bandung, 2012.

Husni Lalu, Pengantar Hukum Ketenagakerjaan Indonesia, Edisi Revisi, PT. RajaGrafindo, Jakarta, 2008.
Martono K. dan Ahmad Sudiro, Hukum Udara Nasional dan internasional Politik, PT RajaGrafindo Persada. Jakarta, 2008.

Martono, Hukum Penerbangan, Mandar Maju, Bandung. 2009.

Martono K., Tim Analisis Awak Pesawat Udara Sipil, Jakarta, 1999. Mauna Boer, Hukum Internasional: Pengertian, Peranan dan Fungsi dalam Era Dinamika Global, P.T Alumni. Bandung. 2011.

Nuh Muhammad. Etika Profesi Hukum. CV. Pustaka Setia. Bandung. 2011.

Putra Bagus Wyasa Ida, Tanggung Jawab Negara Terhadap Dampak Komersialisasi Ruang Angkasa, Refika Aditama, Bandung, 2001.

Soekanto Soerjono dan Sri Mamudji, Penelitian Hukum Normatif Suatu Tinjauan Singkat, PT Raja Grafindo Persada, Jakarta. 1995.

Soekanto Soerjono, Pengantar Penelitian Hukum, UI Press, Jakarta, 2005.

Sudarsono. Kamus Hukum. PT. Rineka Cipta. Jakarta. 2009.

Sudarsono, Pengantar IImu Hukum, Cetakan Kelima, PT. Rineka Cipta, Jakarta, 2007.

Usman, Aspek-Aspek Hukum Perbankan di Indonesia. Penerbit Gramedia Pustaka Utama. Jakarta. 2001.

Wiradipradja Saefullah E., Hukum Transportasi Udara: Dari Warsawa 1929 ke Montreal 1999, PT. Kiblat Buku Utama, 2008.

\section{B. Jurnal}

Lestari Mona, Annisa Rahmawaty, Fenny Etrawati, Nova Apriza Cahyani, Shinta Dwi Kasih, Masayu Gemala Rabiah, Reza Ardiansyah.Persepsi Risiko Penumpang Pesawat Terbang.Jurnal Kesehatan. ISSN 1979-7621 (Print). ISSN 2620-7761 (Online). Vol. 11. No. 2. Desember 2018.

Poerwanto, Eko Uyuunul Mauidzoh. Analisis Kecelakaan Penerbangan Di Indonesia Untuk Peningkatan Keselamatan Penerbangan Jurnal Angkasa Volume Viii, Nomor 2, November 2016. 


\section{Peraturan Perundang-Undangan}

Undang-Undang Nomor 1 Tahun 2009 tentang Penerbangan.

Peraturan Pemerintah Nomor 3 Tahun 2001 tentang Keamanan dan Keselamatan Penerbangan.

Keputusan Presiden Republik Indonesia Nomor 105 Tahun 1999 Tentang Komite Nasional Keselamatan Transportasi.

Peraturan Presiden Republik Indonesia Nomor 2 Tahun 2012 Tentang Komite Nasional Keselamatan Transportasi.

Peraturan Pemerintah Republik Indonesia Nomor 62 Tahun 2013 Tentang Investigasi Kecelakaan Transportasi.

\section{Internet}

http://dephub.go.id.Investigasi Kecelakaan Pesawat Udara Tidak Untuk Penuntutan.Diakses 8/20/2019 8:14 Wita.

https://www.jawapos.com/features/humaniora /DaftarKecelakaan Pesawat di Indonesia 10 Tahun Terakhir. Diakses 8/20/2019 9:02 Wita. http://www.chappyhakim.com/category/article -writing/Polisi dan Kecelakaan Pesawat terbang Diakses 8/20/2019 9:30 Wita.

https://tirto.id/q/humaniora-cPgPeriksa Data Kecelakaan Lion Air \& Teror Kerapnya Kecelakaan Pesawat Terbang. Diakses 8/20/2019 8:30 Wita.

https://nationalgeographic.grid.id/penulis/117 5/national-geographic-indonesiaLima Penyebab Kecelakaan Pesawat yang Paling Umum Terjadi di Dunia. Diakses 8/20/2019 8:56 Wita.

http://www.adobe.com/go/reader9_create_pd f.Nasyithah Az-Zahra Lubis. Kecelakaan pesawat Di wilayah timur indonesia, papua. hlm. 2. Diakses 8/20/2019 9:39.

http://rri.co.id/berita/nasional.html. KNKT dan AIB Tandatangani MoC Bidang Investigasi Kecelakaan Penerbangan. Diakses 8/20/2019 8:28 Wita. 